\title{
論争における問題設定の「ずれ」
}

一筒井康隆「無人警察」をめぐる論争を事例として—

\section{The Divergence of Problem-Setting in Controversy:}

A Case Study of the Controversy on Tsutsui Yasutaka's "Robot Police"

\author{
林 原 玲 洋 \\ HAYASIBARA Akihiro
}

In 1993, the Japan Epilepsy Association criticized Tsutsui Yasutaka's novel "Robot Police" as discriminatory to epileptics, and sought to have it from a textbook published by Kadokawa Publishing. In response to the criticism, he declared a "Writing Strike" and appealed for freedom of expression. This declaration drew public attention, and raised a storm of controversy. The aim of this paper is to explicate the divergence of problem setting in the controversy. First, I will show that the declaration was situated in the context of victim contest. Then, I will demonstrate that the context was prepared through the shift of roles in the early stages of the controversy. Finally, I will present a rhetorical analysis of how the shift of roles occurred in the responsive context of the controversy.

\section{1. 序論：課題の設定}

本稿の目的は、議論を尽くすことでかえって合意から遠ざかってしまう論争の過程、い わば論争のアイロニーを事例に即して描くことで、合意形成論への示唆を得ることであ る。

社会における議論の機能とはなにか。その主要な機能は、民主的な議論を通じた合意形 成に求められることが多い。たとえば、J. Habermas や J. Cohen に代表される討議民主制 論では、民主的な議論を通じて到達した合理的な選択肢が、普遍的な合意形成を導くこと が強調されている。一方、価值の多元化した近代社会では、強い意味での合意形成（理由 の一致による結論の一致）は困難であるとして、より弱い意味での合意形成（理由の一致 を問わない結論の一致）を志向する立場もある。たとえば、J. Rawls の「重なり合う合意」 論は、その一種といえるだろう。

討議民主制論に与するか否かにかかわらず、ここにはひとつの前提があるのではないだ ろうか。それは、すくなくとも価值を共有する場合は、議論を通じた（理由の一致による） 結論の一致が導かれるはずだ、という前提である。ここで、価值の普遍化が可能であると 考えれば討議民主制論に、価值の普遍化を断念して、議論以外の回路（交渉など）を通じ た結論の一致を模索すれば「重なり合う合意」論になろう。だが、いずれも、共有価值か ら結論にいたる筋道は合理的に一本化できると考える点では、おなじ前提に立っている。

しかし、C. Mouffe やW. E. Connolly も指摘するように、実際の議論はより論争的なも のである。つまり、当初は共有されていた価值が、議論を通じて多元化していくことがあ る。そのことを、私たちは「ずれる」「すれ違う」「かみ合わない」議論として経験してい る。あらかじめ対立している価值の表現としてではなく、いま・ここで価值が多元化して いく偶発的な過程として論争を経験するとき、私たちはこれらの語彙を用いるのである。

先行研究では、議論が依拠する価值を解明するため、結論と論拠を結びつける解釈枠組 
が分析されてきた [林原 2003; 2005］。たとえば、P. R. Ibarra と J. I. Kitsuse [1993] はそ のような枠組を「レトリカル・イディオム」とよび、人工妊娠中絶をめぐる論争を、胎児 の生命に価值をおく「喪失のレトリック」と、女性による選択に価值をおく「権利のレト リック」の対立と位置づけている。また、D. A. Schön [1993] は同様の枠組を「問題設定 (problem-setting)」とよび、スラム街をめぐる議論の問題設定が、「スラム街＝病気」お よび「スラム街＝自然」というメタファーによって左右されるとしている。

以下、ある結論の是非（争点）を問うため、どのような論拠の有無（論点）について論 ずるべきかを指示する解釈枠組を、Schön にならって「問題設定」と呼ぶことにしよう。 各々の議論の問題設定を取りだし、その対立として論争を描く研究は無数にある。価值の 多元化した近代社会をとらえるうえで、それらの研究には一定の認識利得があろう。だが、 それらは、議論が「ずれる」過程を解明するものではない。そこで本稿では、当初は共有 されていた問題設定が、次第に「ずれて」いくような論争の事例を取りあげ、その過程を 描きたい。「近代社会とはなにか」という問いにならぶ社会学の根本問題、つまり、「合理 性とはなにか」という問いに取りくむうえで、いま・ここで価值が多元化していく論争を 研究することは、重要な意義を持つはずである。

問題設定が次第に「ずれて」いくような論争の事例として本稿で取りあげるのが、差別 表現をめぐる論争、なかでも筒井康隆の「無人警察」をめぐる論争である ${ }^{(1)}$ 。

古くから差別表現は、被差別者にとって切実な問題であると同時に、その告発は反差別 運動の重要な手がかりでもあった。とりわけ 1970 年代になると、エスニシティ・障碍・ ジェンダー・人種・セクシュアリティなど多様な領域において、差別表現が社会問題化さ れるようになる。一方、差別表現の社会問題化は、告発の宛先である表現者やメディアか ら「言葉狩り」として強く反発され、しばしば大規模な論争をひきおこした。それらは、 「差別表現ではないか」という問い・主張に対して、「言葉狩りではないか」と反問・応酬 するものであり、結論の不一致という対立以前に、結論と論拠を結びつける問題設定が対 立する論争になっている。表現規制の是非について、「表現の差別性」という問題設定で 論ずるのか、「表現の自由」という問題設定で論ずるのか。これがそもそも対立している からである。

そして、近年最も世間の注目をあつめた差別表現論争が、「無人警察」論争である。八 木晃介 [1994:2] も指摘するように、この論争は、マスメディアをアリーナとして大規 模に展開された点に、それまでの差別表現論争にはみられない顕著な特徴があった。その 社会学的な分析はすでに試みられているが [伊藤 2006; 佐藤 2005]、それらの先行研究は、 あらかじめ対立している問題設定の反映として、「無人警察」論争を描いている。それに 対して本稿では、「無人警察」論争の問題設定は最初から対立していたのではなく、論争 の過程において「ずれて」いったと考える。まずは次節でそのことを確認しよう。

\section{2.「無人警察」論争における問題設定の「ずれ」}

「無人警察」は、人間の脳波を感知して取り締まりをおこなう「ロボット巡査」が登場 する近未来を舞台に、管理社会の不気味さを描く、という筋立ての短編 SF 小説で、1965 年に『科学朝日』誌上で発表され、1983 年に『筒井康隆全集』の第 1 巻に収録された。

論争の発端は、1994 年度から使用予定であった角川書店発行の高校教科書『国語 I』に この小説が収録され、文部省 [当時] の教科書検定を通過したことであった。その描写を 
問題視した日本てんかん協会は、1993 年 7 月、「てんかんに対する差別を助長する」とし て、(1)教科書の販売中止、(2)「無人警察」が収録された全集や文庫の回収、および、(3)謝 罪を求めて抗議をおこなったのである。協会が問題とした箇所は、「てんかんを起こすお それのある者が運転していると危険だから、脳波測定機で運転者の脳波を検査する。異常 波を出している者は、発作を起こす前に病院へ収容されるのである」という部分と、「わ たしはてんかんではないはずだし、もちろん酒も飲んでいない。何も悪いことをした覚え もないのだ」という部分であった(2)。

この論争は、1993 年 9 月、筒井が「断筆宣言」、つまり、一切の執筆活動の停止を宣言 するという衝撃的な手段をとって、表現の自由を訴えたことにより、にわかに世間の注目 をあつめることになる。以下、初期／中期／後期という３つの時期（ないし位相）に区別 してその経過をふりかえってみよう(3)。

初期は、協会による抗議から「断筆宣言」までである。「無人警察」の差別性を主張す る協会とこれを否定する角川・筒井の間で議論がかわされたが、合意にはいたらなかっ た。

中期は、「断筆宣言」から、協会と筒井の間に「合意」（1994 年 11 月）が成立するまで である。月刊『創』編集長の篠田博之が仲介し、協会と筒井の間で交渉がおこなわれた。 この「合意」により、(1)筒井は、教科書から「無人警察」をひきあげること、そして、(2) 協会は、全集や文庫の回収、また、表現の訂正を求めないことが確認された。

後期は、時期的には中期と重複するのだが、「断筆宣言」以降、および、「合意」の成立 以降である。「断筆宣言」に対する反応として、当事者（協会・角川・筒井）以外の様々 な論者が発言をおこない、多くの書籍が出版された。

論争の以上のような経過は、その渦中にあった当事者からも、後期になって参加した一 般の論者からむ、どこか議論が「ずれて」[塩見 1993:4] いるものと認識された。

「無人警察」論争の初期には、あくまでも「無人警察」という特定の作品が、てんかん を持つ者に対して差別的であるか否か、そして、それを教科書から削除すべきか否かが争 われた。協会は「『無人警察』は差別的なので、削除すべきである」と主張し、角川・筒 井は「『無人警察』は差別的ではないので、削除する必要はない」と主張したわけである。 初期の論争は、「表現の差別性」という問題設定のもとでおこなわれたといえるだろう。 つまり、(1)個別的な表現規制の是非を問うため（争点）、(2)その表現が差別的であるか否 かを論ずる（論点）、という問題設定である。

ところが、「断筆宣言」から「合意」にいたる過程において、「表現の差別性」という問 題設定は、後景に退くことになる。中期におこなわれた交渉の帰結である「合意」に、そ のことが決定的にあらわれている。つまり、「合意」における筒井の立場は、「『無人警察』 の差別性はみとめないが、その教科書からの削除には同意する」というものだったのであ る。「ねじれ合意」と評するむきもあったこの「合意」を、仲介者であった篠田は、以下 のように総括している。

「無人警察」が差別的表現であるかいなか、という根本的問題では対立は残ったままである。し かし「教科書問題」にけりをつけるという点では双方の利害が一致した。それが「合意」の意味で ある。それ以上でもないし、それ以下でもない。根本的解決になっていないではないか、という批 判はまちがいではないのだが、「合意」が根本的解決だとは初めから当事者のいずれもが言ってい ないのである。[篠田 1995:227-228] 
「表現の差別性」にかわり、後期の論争で優勢になったのが、「表現の自由」という問題 設定であった。つまり、(1)一般的な表現規制の是非を問うため（争点）、(2)表現の自由に 規制・糾弾の権利が優先するか否かを論ずる（論点）、という問題設定である。もはや、 議論の中心的な主題は、「無人警察」という特定の作品でも、てんかん差別という具体的 な問題でもなくなってしまう。だが、論争のこのような展開は、協会にとって「納得でき ない」[松友 1994 : 再録 53] ものであった。

\section{3. 被害者コンテストのリソースとしての問題設定}

前節では、「無人警察」論争の経過をたどりながら、初期には共有されていた「表現の 差別性」から、これと対立する「表現の自由」へと、問題設定が「ずれて」いったことを 確認した。この「ずれ」は、単なる話題変更とは異なるものであることに注意したい。論 争における問題設定の「ずれ」は、一方には歓迎されたとしても、他方には「納得できな い」そういう非対称な帰結をともなう変化なのである。

この非対称性に関してしばしば指摘されるのが、「断筆宣言」が持っていたドラマ性と、 それにともなうアリーナ（public arena）の変容である ${ }^{(4)}$ 。伊藤高史は、「無人警察」をめ ぐる論争を、「筒井が断筆宣言をするや否や、問題は差別的表現規制の問題へと棚上げさ れ、てんかん差別は問題の枠組みから消し去られてしまった」［伊藤 $2006: 158$ ］と評した うえで、その原因を、「表現の自由」という概念が果たした話題選択の機能に求めている。 「断筆宣言」をうけて様々な論者が発言するようになると、「表現の自由」という概念は、 「多様な議論を紹介して、その判断を受け手に委ねるという態度をメディアに選択」[伊藤 2006 : 149] させた。だが、この一見したところ中立的なメディアの態度は、結果として、 てんかん差別の問題を問題設定から消去するように機能した。なぜなら、「限られたメ ディアを利用できる」「思想の市場における強者」 [伊藤 $2006: 162$ ] は、被差別者側では なく、筒井のような表現者側だったからである。

伊藤の指摘は重要であるが、これは問題設定の「ずれ」を説明したものではない。つま り、対立する問題設定のうち一方が優勢になった過程（問題設定の競争・選択過程）の説 明ではあっても、そもそも対立的な問題設定が生じた過程（問題設定の変異過程）の説明 にはなっていない。だが、前節で確認したように、「無人警察」論争は、その初期におい ては「表現の差別性」という問題設定を共有していたのである。ここから「表現の自由」 へと問題設定が「ずれた」のはなぜか。これを解明するには、筒井による「断筆宣言」が、 どのような状況に対するリアクションであったのかを理解する必要がある。

「断筆宣言」において、筒井は以下のように述べている。

この断筆宣言は、直接には日本頡痛協会などの紏弾への抗議でもあるが、また、自由に小説が書 けない社会的状況や、及び、そうした社会の風潮を是認したり、見て見好りをしたりする気配が、 本来なら一般的良識に阿ることなく、そもそもは「反制度的でなくてはならない小説」に理解を示 すべき筈の多くの言論媒体にまで見られる傾向に対しての抗議でもある。人権問題、差別問題、こ とば狩りなどに関するジャーナリズムの思想的脆弱性に対しては、強く疑念を呈しておく。今回は、

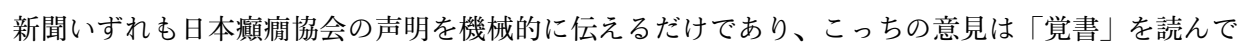
いながら触ら阵神に崇りなしと見て見振りの知らん顔、まったく載せてくれなかった。例の永山 問題で文芸家協会も脱会しているから、そっちからの支援も期待できず、ひとりで戦うしかなかっ た。(中略)

これは現在の「ことば狩り」「描写狩り」「表現狩り」が「小説狩り」に移行しつつある傾向を感 
じ取った一作家のささやかな抗議である。おわりに、強く言う。文化国家の、文化としての小説か、

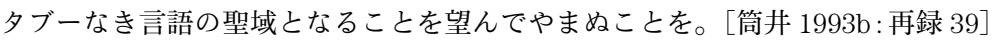

ここで筒井がおこなっていることは、単に「表現の自由」という問題設定（ジャーナリ ズム論）を提起することではない。のちに筒井が「このままではおれだけが悪者になって しまう、と、思ったことが断筆宣言の理由のひとつである」[筒井 $1993 \mathrm{c}$ : 再録 44] とし ているように、ここで筒井は、「言語の聖域」を保護するために「戦う」者として自らの 役割を再定義し、「支援」を呼びかけているのである。つまり、筒井の「断筆宣言」は、 被害者コンテスト（victim contest）の文脈において生じたといえるだろう(5)。

「表現の差別性」という問題設定にもとづく初期の論争において、「被害者」は差別告発 側である協会、「加害者」は差別否定側である角川・筒井であった。もちろん、角川・筒 井にしてみれば、そのような役割定義は、それ自体争われるべきものであろう。だが、す くなくともその逆の役割定義が支配的になることは、初期の段階ではありそうにない。つ まり、協会を「加害者」、角川・筒井を「被害者」とする定義は、この段階では無理があ る。

この役割定義を、筒井は「断筆宣言」によって逆転しようとした。つまり、協会と筒井 の対立は、差別告発側と差別否定側の対立というよりも、規制推進側と規制反対側の対立 であり、真の「加害者」は、「小説狩り」によって「言語の聖域」を侵害する協会の方だ、 というわけである。このとき、失われていく小説の保護者である筒井は、むしろ「被害者」 の側に立つことになる。「表現の自由」という問題設定は、以上のような被害者コンテス トのリソースとして、論争に組みこまれたのである(6)。

\section{4. 論争における役割の転換と被害者コンテスト}

前節では、問題設定の「ずれ」がもたらす非対称な帰結に関して、しばしば指摘される アリーナの変容は、問題設定が「ずれる」過程を説明しないことを指摘した。そして、 「無人警察」論争における「表現の自由」という問題設定は、いずれが真の「被害者」「加 害者」なのかを争う解釈過程（被害者コンテスト）のリソースとして、論争に組みこまれ たという解釈を示した。「表現の差別性」から「表現の自由」へという問題設定の「ずれ」 が、単なる話題変更にとどまらないことは、ここまでの分析からあきらかであろう。被害 者コンテストには、当事者のアイデンティティが賭けられている。協会にとって自らの役 割が「加害者」になることは、断じて容認できないのである。

さて、筒井も述べているように、「断筆宣言は、直接には日本癲疭協会などの紏弾への 抗議」[筒井 $1993 \mathrm{~b}$ : 再録 39］であった。つまり、筒井の「断筆宣言」は、メディアに対 するリアクションでもあったが、直接には協会に対するリアクションだったのである。上 述のような被害者コンテストが生じた、そもそもの経緯を理解するには、「断筆宣言」以 前における協会と筒井のやりとり、つまり、「無人警察」論争の初期に着目する必要があ ろう。

表一 1 は、初期の論争においてやりとりされた文書をまとめたものである。「抗議」と 「声明」は、協会による立論。「回答」と「覚書」は、角川・筒井による反論。協会の「意 見」は、「回答」に対する再反論。そして、「覚書について」は、高橋哲郎・日本てんかん 協会会長 [当時］によるもので、「覚書」に対する再反論になっている。

「表現の差別性」という問題設定を共有していた初期の論争において、主要な論点は 
表ー 1 「無人警察」をめぐる初期の論争（1993 年）

\begin{tabular}{|c|c|c|}
\hline & 文書 & 論 争 \\
\hline $7 / 8$ & 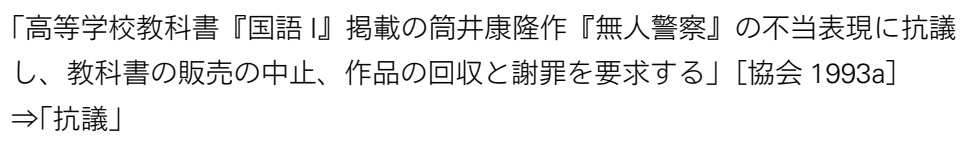 & \multirow{2}{*}{ 立論 } \\
\hline $7 / 10$ & $\begin{array}{l}\text { 「角川書店発行、高等学校教科書『国語 I』に対する抗議ならびに採択と使用 } \\
\text { の中止を求める要求について (声明)」[協会 1993b] } \Rightarrow 「 \text { 声明」 }\end{array}$ & \\
\hline $8 / 5$ & $\begin{array}{l}\text { 「7月 } 8 \text { 日付抗議文に対する回答書」[角川 1993] } \Rightarrow 「 \text { 回答」 } \\
\text { 「覚書」[筒井 1993a] }\end{array}$ & 反論 \\
\hline $8 / 6$ & 「『7 月 8 日付抗議文に対する回答書』への意見」[協会 1993c] $\Rightarrow\lceil$ 意見」 & \multirow{2}{*}{ 再反論 } \\
\hline $9 / 7$ & 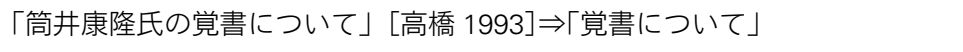 & \\
\hline $9 / 10$ & 「断筆宣言」[筒井 1993b] & \\
\hline
\end{tabular}

出典：月刊『創』編集部編 [1995］より作成 [ $\Rightarrow$ の右側は本稿における略称 $]$

「『無人警察』が差別的であるか否か」というものであった。ここで、ある表現が差別的で あるか否かを論ずるためには、さらに下位の論点が必要になる。佐藤裕［2005］も同様の 指摘をしているが、そのような下位の論点は、大きくわけて 3 つあった。つまり、1 かんの描写に偏見がある（間違っている）加否か、(2)教科書を使用する高校生に被害があ るか否か、そして、(3)角川・筒井に差別意識があったか否か、という3つの論点である。 両者とも（協会も角川・筒井も）、これら 3 つの論点について、それぞれ立論一反論一再 反論をおこなっているのだが、ここで注目したいのは、立論から再反論にいたる過程にお いて、被害者コンテストの文脈がすでに準備されていた点である。

立論において協会は、「無人警察」が差別的である理由を 5 点あげていた。

「異常波を出している者は、発作を起こす前に病院へ収容されるのである。」などということは、著 者の意図がどうであろうと、てんかんをもつ人々の人権を無視した表現であり、また医学的にもて んかんに対する間違った考えに立脚するものである。(中略)

第 2 に、てんかんが悪者扱いされていることも、私たちの見逃すことのできない問題である。… …前段ではてんかんが悪いことの一つのように書かれ、後段では脳波と思考波の違いについて何も 説明されていないのだから、それを一層強める結果となっている。

第 3 には、てんかんをもつ人々の自動車運転についても、極めて時代遅れの考えを述へているこ とである。(中略)

第 4 に、この教科書は「てんかん」を問題にしながら、てんかんと脳波の関係について医学的に あ誤った説明しか与えていないことである。(中略)

最後にこれを教科書として使用した場合、そこにいるてんかんをもつ高校生や、近親者にてんか んをもつ人がいる高校生は、どのような思いで授業に臨まねばならないことになるのか、教科書の

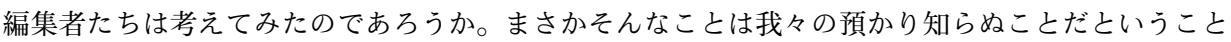
はないであろう。教育者ならば、思春期にあたる高校生を傷つけるようなことは絶対に避けなけれ 
ばならないはずである。[協会 $1993 \mathrm{~b}$ : 再録 24-25]

以上のうち、第 1 ・第 3 ・第 4 の理由は論点 (1)（偏見の有無）に、第 5 の理由は論点(2) （被害の有無）に、そして、第 2 の理由は論点(3)（差別意識の有無）に相当する。この段 階でも差別意識の有無が問題になっていないわけではないが、あくまでも力点は、描写の 医学的・時代的な正確性（論点(1)）と、高校生に対する影響（論点(2)）にあった。

だが、再反論において協会は、角川・筒井の差別意識をより厳しく追及するようになる。 たとえば、以下は、角川の「回答」を引用しつつ、その差別意識を問うている箇所であ る。

「輝かしい未来であれば、てんかんに限らず、病気そのものを克服すべきはずですが」とあるが、 なぜ克服していないのか、それは「取り締まり社会」の問題とはまったく別個の問題であり、との 言葉自体の中に、てんかんに対する偏見が存在していると言わねばならない。[協会 $1993 \mathrm{c}$ : 再録 $33]$

また、以下は、筒井の「覚書」や別の筒井作品（「乱調人間大研究」）を引用しつつ、そ の差別意識を問うている箇所である。

筒井氏は、「この作品（『無人警察』）において、てんかんをもつ人を差別する意図はなかった」 と述べていますが、同時期にこの小説のための調查を基礎に作ったという別の作品で、てんかんに ついてこれだけひどいことを書いている作者か、てんかんを差別する意図はなかったといわれても、 それを信じろという方が無理なことです。

貴殿の覚書はまず第一に、てんかんをもつ人々を侮辱している部分はこっそり隠し、真ん中だけ を載せているという点で、恐ろしくアンフェアな文章です。[高橋 1993: 再録 34]

いずれも、「無人警察」それ自体ではなく、角川・筒井が書いた別の文書を論拠として、 その差別意識を対人論証（人格攻撃； ad hominem）的に追及している点が特徵的である。 だが、相手に差別意識があることの立証は、てんかん描写の間違いを指摘することや、高 校生に生じる被害を指摘することにくらべ、困難な作業である。そのため、差別意識の有 無という論点に割かれる紙幅も、立論の段階より多くなっている。立論から再反論にいた る過程において、協会はより困難な役割を引きうけることになった、といえるだろう。

ここで協会が引きうけることになった役割は、あくまでも論争において論者が果たすべ き役割（論証役割［林原 2006；2008］）であり、「被害者」「加害者」といった役割とは異 なる。だが、筒井が「断筆宣言」によって反応した被害者コンテストの文脈は、論争にお ける協会の役割が転換したことによって、すでに準備されていたと考えてよいだろう。の ちに筒井が「断筆宣言」の理由を「過去の作品の洗い出しが始まっていたから」[筒井 1993c: 再録 46] としているように、協会が対人論証的な追及を開始したことは、「自分の 過去の作品を守る」[筒井 1993c: 再録 46] よう筒井を動機づけた。これはまさに、協会 を「加害者」、筒井を「被害者」として再定義する過程の第一歩だったのである。

\section{5.レトリカルな応酬における役割の転換}

第 3 節では、「無人警察」論争における問題設定の「ずれ」が、被害者コンテストの文 脈において生じたことを、前節では、その文脈が論争における協会の役割の転換によって 準備されていたことを、それぞれ論じた。では、「無人警察」論争における問題設定の 「ずれ」は、協会が一方的に対人論証的な追及を開始したために生じた、そう解釈してよ 
いのだろうか。そうではないことを示すため、本節では、論争における役割の転換を、レ トリカルな応酬という文脈に位置づけて解釈してみたい。

\section{（1）「小説は例外」という対抗レトリック}

前節でも触れたように、角川・筒井は、偏見・被害・差別意識の有無という3つの論点 について、それぞれ反論をおこなっている。ただし、偏見や被害の有無という論点に関す る反論には、差別意識の有無という論点に関する反論にはない特徵がみられる。

まず、角川の「回答」は、「無人警察」が、その舞台となっている管理社会を、最終的 には否定的に描いていることを強調する。

「無人警察」は一読して分かりますように、近未来を描いた SF 小説です。交通違反の取り締ま りの手段として、速度検查機・アルコール摂取量探知機・脳波測定機などで人間を類別し、支配統 制しようとする社会を好意的に見ていた主人公が、ある日突然反逆せざるをえない状況まで追い詰 められてしまう過程を描いた作品です。管理統制された未来を讃える作品ではありません。人間が ロボットに潜在意識まで探られてしまう結末から、文明とは何か、人間のアイデンティティーとは 何かを問い掛けている作品です。このような読み取りに立脚して、初めててんかん云々の論議が出 来るのです。[角川 1993 : 再録 27]

そのうえで、「声明」で協会があげた第 1 の理由に対して、以下のように反論している。

さて、(1)の「てんかんは取り締まりの対象としてのみ扱われ、医学や福祉の対象としては全く考 えられていない」と言うのは、交通違反の取り締まりの対象としてはまさにその通りと言わざるを えません。…...輝かしい未来であれば、てんかんに限らず、病気そのものを克服すべきはずですが、 残念ながらこの小説で描かれている未来社会は、取り締まりに重点を置く社会であります。[角川 1993 : 再録 27]

角川によるこの反論は、偏見の有無という論点に関し、小説を例外として位置づけるも のである。つまり、かりにその表現に偏見が含まれるとしても、「無人警察」はフィク ションであり、偏見にみちた未来社会を否定的に描いているため、差別表現であるとはい えない、というわけである。

これと同様の反論を、被害の有無という論点に関しておこなったのが、筒井の「覚書」 である。「声明」で協会があげていた第 5 の理由に対して、筒井は以下のように述べてい る。

(5)に対しては、結局文学論で答えるしかありません。小説は、作家がそれをひとつ書くたびに必 ず誰かを傷つけているという芸術形式だからです。作家がひとり世に出れば、通常その周囲は死屍 累々、特に日本の私小説などでは多く家族親戚を傷つけ、他人を傷つけ、そのことによって本人も 傷つきます。欧米では小説のこうした不可避的な機能を逆手にとったブラック・ユーモアの伝統が あります。[筒井 1993a : 再録 31-32]

かりにその表現が被害をもたらすとしても、すべて小説はひとを傷つけるため、差別表 現であるとはいえない一一筒井の主張を要約すればこのようになるだろう。

Ibarra と Kitsuse [1993］は、対論者による問題の特性記述に一応の賛意を示したうえで、 べつの理由を提示して相手が提案した解決法を批判するという言説的な技法を、「共感的 な対抗レトリック（sympathetic counterrhetoric）」と呼んでいる。小説を例外として位置 づける以上のような反論もまた、これに類する指し手といえるだろう。角川も筒井も、偏 見や被害の存在を直接否定するのではなく、偏見や被害の存在を一応みとめたうえで、そ 
れでも問題がないと主張しているからである。ここで、共感的な対抗レトリックへの再反 論には、独特の困難がともなうことに注意したい。偏見や被害の存在を対論者が直接否定 していれば、これに対する再反論は比較的容易である。つまり、てんかん描写の間違いや 被害者の証言を具体的に提示すればよい。もちろん、それで対論者が納得するとはかぎら ないが、すくなくとも適切な再反論をおもいつかないということはない。だが、「小説は 例外」という反論に対しては、どのような再反論が適切なのかが不明確なのである。

\section{（2）対抗レトリックを支えるモチーフ}

そもそも、小説が例外であるのはなぜか。「無人警察」が偏見にみちた未来社会を否定 的に描いているとしても、また、ブラック・ユーモアがひとを傷つける芸術形式であると しても、だから問題がないということには必ずしもならない。この点について、角川・筒 井が明示的な理由をあげていれば、その理由を否定することが適切な再反論となるだろ う。

だが、角川も筒井も、小説が例外であるための明示的な理由をあげていない。かわりに 議論を文彩（あや）どっているのが、小説の例外的な位置づけを支える様々なモチーフ (motif) である。Ibarra と Kitsuse によると、モチーフとは、「状態カテゴリーの要約的な 記述や評価として機能する文彩」 [Ibarra \& Kitsuse 1993: 35] であり、「水山の一角（tip of the iceberg)」や「対 ○戦争（the war on）」といった定型表現のことである。モチー フは、特定のイメージを喚起することによって、問題の特性記述に一役かう。たとえば、 「水山の一角」というモチーフは、申し立てられている問題の規模を強調するのに役立つ だろう。

結論からいえば、角川・筒井による反論では、言葉をめぐる様々なメタファー [林原 2006; 2008］が、小説の例外的な位置づけを支えるモチーフになっている。

たとえば、角川の「回答」は、未来社会を否定的に描くという筒井の思想を、正しく 「読み取り」「把握」する重要性を再三強調している。この表現は、あたかも小説という入 れ物（容器）のなかに、著者の思想が品物のように存在し、それを「取る」「つかむ」こ とこそが小説の読解である、というシナリオを喚起する。また、おなじく「回答」では、 てんかん描写に関する十分な注釈を小説に書き込むと、「小説が壊れ、文学作品としての 体をなしえない」[角川 1993:再録 27］と主張している。この表現は、あたかも「壊れ物」 （壊れやすい品物）であるかのように小説をとらえるものといえるだろう。

さらに印象的なモチーフは、文学者である筒井の「覚書」にみることができる。前項で 引用した箇所にも、「必ず誰かを傷つけている」「死屍累々」「家族親戚を傷つけ」「他人を 傷つけ」「本人も傷つきます」という表現がみられるが、このほかにも筒井は、「仮面を剥 いで」「ブラック・ユーモアの毒」「毒の矢」「毒の効果」のように [筒井 1993a: 再録 32]、 小説を武器に喻えるメタファーを多用している。

そもそも、言葉を武器に喻えるメタファーは、「無人警察」が「高校生を傷つける」[協 会 1993b : 再録 25］として、協会が用いた表現であった。英語でも、ヘイト・スピーチを 「傷つく言葉 (words that wound)」と表現することがあるように、このメタファーは差別 告発側にひろく共有されている。それを筒井は、傷つく表現／傷つかない表現という区別 を消し去るほど過剩なまでに強化することで、差別を否定する議論に活用したのである。

角川・筒井が用いた以上のようなメタファーは、いずれも小説の例外的な位置づけを支 
えるモチーフになっている。これらのモチーフは、小説が例外であるための明示的な理由 ではないため、それ自体に反論することは難しい。O. Reboul は、言い換え不可能なレト リックを用いた議論には、「相手に反駁を許さない」[Reboul 1990 : 訳 113] 閉鎖性がある と指摘しているが、まさに角川・筒井の反論はそのような閉鎖性を持っていたといえるだ ろう。

\section{（3）レトリカルな応酬における役割の転換}

前節では、「無人警察」論争の初期において、協会の役割が対人論証的な追及へと転換 したことを指摘した。本節であきらかにしたように、この転換は、協会が一方的に主張の 力点を変えたために生じたわけではない。角川・筒井は、小説を例外とする反論を展開し、 しかもこれを様々なモチーフによって文彩どった。そのため、偏見や被害の有無という論 点については、適切な再反論が困難になった。そこで、のこる論点である差別意識の有無 が、協会による再反論の中心に浮上したのである。こうした論争の展開は、互いが互いの 指し手に依存して、はじめて可能になるものである。

つまり、「無人警察」論争における役割の転換は、対抗レトリックやモチーフを用いた レトリカルな反論への再反論という応答的な文脈において、独話的にではなく、対話的 （相互行為的）に生じたといえるだろう。角川・筒井が別様に反論していれば、また、協 会が別様に再反論していれば、役割の転換もまた別様でありえたのである。

\section{6. 結論 : 今後の課題}

以上本稿では、論争における問題設定の「ずれ」を描くため、「無人警察」論争を事例 として取りあげ、まずはその初期から後期にかけて、「表現の差別性」という問題設定が 「表現の自由」という問題設定へ「ずれて」いったことを確認した。この「ずれ」が持つ 非対称な帰結は、「断筆宣言」を契機とするアリーナの変容によってしばしば解釈される。 だが、この解釈は、問題設定の「ずれ」を説明するものではなかった。そこで、本稿では、 「断筆宣言」が位置づけられている文脈として、被害者コンテストの存在を指摘し、「表現 の自由」という問題設定は、そのリソースとして論争に組みこまれたという解釈を提示し た。さらに、この被害者コンテストは、協会の役割が対人論証的な追及へと転換すること により、初期の論争においてすでに準備されていたことを指摘した。最後に、この役割の 転換は、協会の一方的な行為によってではなく、協会と角川・筒井の相互行為によって対 話的に生じたことを、レトリック分析によってあきらかにした。

図一 1 は、本稿の分析結果を、論争の初期と後期、および、論点と役割の水準を区別し て整理したものである。論争において問題設定が「ずれる」ことは、ありふれた出来事で

\section{【初期】}

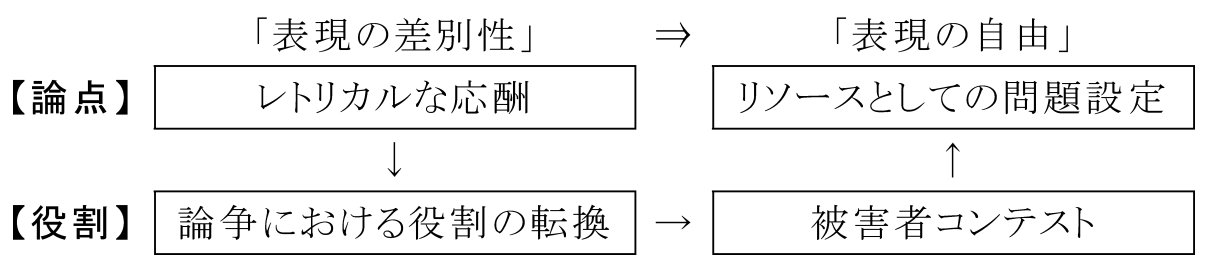

図-1 「無人警察」論争における問題設定の「ずれ」 
ある。だが、そのしくみを具体的に描いた研究はなかった。図－1の枠組は「無人警察」 論争という個別の事例から取りだしたものだが、今後の研究の準拠枠になるだろう。

ここで、本稿の出発点となった問いに立ちかえろう。つまり、社会における議論の機能 とはなにか、という問いである。「無人警察」論争が示唆するのは、議論を尽くそうとす るそれ自体としては合理的な態度が、かえって合意の条件を掘りくずす（論争のアイロ ニー）ということであった。協会と角川・筒井のレトリカルな応酬は、一方が「詭弁」や 「誤謬」に陥っているから生じたわけではない。いずれの議論も、それなりに筋が通って いる。だが、互いに筋道を立てることが、かえって役割の転換を生じさせ（被害者コンテ スト)、ひいては対立的な問題設定を呼びこんだのである（リソースとしての問題設定）。

もっとも、議論を尽くすことが問題設定の「ずれ」を生じさせるとしても、そのことが ただちに合意形成を阻害するとはいえない。「無人警察」論争における中期の「合意」は、 当事者が「議論」を断念し、コミュニケーション回路を「交渉」へ変更することによって 達成された。だが、この断念は、初期の論争を通じて問題設定の「ずれ」が決定的になっ ていたからこそ、可能になったともいえるだろう。

いわば、「無人警察」論争における問題設定の「ずれ」は、強い合意（理由の一致によ る結論の一致）の条件を掘りくずすことで、弱い合意（理由の一致を問わない結論の一致） の条件を整えたわけである。ただし、ここには、慎重に検討しなければならない問題がひ とつ残っている。それは、「無人警察」論争における問題設定の「ずれ」には、当事者の アイデンティティが賭けられていたという点である。はたして協会は、「合意」によって、 自らのアイデンティティを「交渉」に差し出したことになるのだろうか。この問いに答え るには後期の論争を精査しなければならない。だが、その検討は別稿を期することにしよ う。

註

（1）本稿で「無人警察」論争を取りあげた理由は2つある。まずは、(1)問題設定が最初から対立していた のではなく、次第に「ずれて」いくような論争の事例であること。そして、(2)そのような「ずれ」を、 論争の当事者む認識・表明していることである。

（2）ここでは、月刊『創』編集部 [1995:10-11] が再録した、角川教科書版「無人警察」の文章を引用 した。『筒井康隆全集』では、「てんかん」の表記が「テンカン」に、「わたしはてんかんではない」 が「わたしにはテンカンの素質はない」となっている [筒井 1983:233-234]。

（3）この時期区分は、論争の当事者による「ずれ」の認識・表明を基準にしたものである。「断筆宣言」 をうけて、松友了・日本てんかん協会常務理事 [当時] が「筒井さんのパフォーマンスに乗って、メ ディアの自主規制に話が移っている」[松友 1994 : 再録 53] と表明したように、また、「合意」をう けて、筒井が「これからの敵は、君たちマスコミだ」[筒井 1994］と表明したように、「断筆宣言」 と「合意」は、この論争の展開にとって重要な契機であった。

（4）S. Hilgartner と C. L. Bosk [1988］は、世間の注目（public attention）が希少資源であり、マスメ ディアをはじめとする各種のアリーナには、社会問題を話題にする容量（carrying capacity）に限界 があることを指摘したうえで、複数の社会問題や問題設定の間に生じる競争・選択過程を、アリーナ の種類に応じて分析するという研究枠組を提案した。なお、本稿における「アリーナの変容」とは、 問題設定の競争過程に扔いて注目の配分に変化が生じることを指している。

（5）J. A. Holstein と G. Miller [1990] は、「被害者（victim)」というカテゴリーを解釈装置としてとらえ なおし、「被害者化（victimization）」が、問題となっている事態について、「加害者」側にその原因を 帰属し「被害者」側の責任を軽減する、相互行為的な解釈過程であること、また、その解釈は、だれ が真の「被害者」「加害者」なのかをめぐって対立する場合があることを指摘した。 
（6）論争のその後の展開は、はたして筒井の企図どおりになった。「断筆宣言」によるアリーナの変容は、 同時に協会を「加害者」とする役割定義を優勢にしたのである。協会を「差別撤廃ファシスト」[安 原 1993: 82] と呼んで批判した安原顯は極端な例としても、差別表現の規制を「検閲」や「言論弾圧」 に喻える議論は、筒井の側についた論者に支配的な論調であった［曽野 1993］。

\section{文献}

月刊『創』編集部（編）1995『筒井康隆「断筆」めぐる大論争』創出版. $\Rightarrow$ 『大論争』

林原玲洋 2003 「S. Toulmin の議論モデル・再考：相互行為としての論争／規範としての論理」『現代社会 理論研究』13: 204-214.

2005「論証と文彩：レトリック論のふたつの系譜と構築主義の社会学」『現代社会理論研究』15: 85-97.

— 2006 「論証役割とメタファー：レトリック分析の社会学的可能性に関する一考察」『先端社会研究』 4: $475-497$.

— 2008 『議論と論争のレトリック分析：論法・メタファー・論証役割』東京都立大学大学院社会科 学研究科平成 19 年度博士論文.

Hilgartner, S. \& Bosk, C. L. 1988 "The Rise and Fall of Social Problems: A Public Arenas Model," American Journal of Sociology 94(1): 53-78.

Holstein, J. A. \& Miller, G. 1990 "Rethinking Victimization: An Interactional Approach to Victimology," Symbolic Interaction 13: 101-120.

Ibarra, P. R. \& Kitsuse, J. I. 1993 "Vernacular Constituents of Moral Discourse: An Interactionist Proposal for the Study of Social Problems," J. A. Holstein \& G. Miller (eds.) Reconsidering Social Constructionism: Debates in Social Problems Theory. Aldine de Gruyter, pp. 25-58. 中河伸俊（訳）「道徳的ディスコース の日常言語的な構成要素：相互作用論の立場からの社会問題研究のための一提案」平 英美・中河伸 俊（編）『構築主義の社会学：論争之議論のエスノグラフィー』世界思想社 2000, pp. 46-104.

伊藤高史 2006 『表現の自由」の社会学：差別的表現と管理社会をめぐる分析』八千代出版.

角川書店 $1993\lceil 7$ 月 8 日付抗議文に対する回答書」再録 :『大論争』pp. 25-29.

松友 了 1994 「断筆宣言その後・下：『差別する自由』は危険」再録 :『大論争』pp. 53-54.

日本てんかん協会 $1993 \mathrm{a}$ 「高等学校教科書『国語 I』掲載の筒井康隆作『無人警察』の不当表現に抗議し、 教科書の販売の中止、作品の回収と謝罪を要求する」再録：『大論争』p. 23.

— 1993b「角川書店発行、高等学校教科書『国語 I』に対する抗議ならびに採択と使用の中止を求め る要求について (声明)」再録 :『大論争』pp. 23-25.

$1993 \mathrm{c} 『$ 『7 月 8 日付抗議文に対する回答書』への意見」再録『大論争』pp. 32-33.

Reboul, O. 1990 La rhétorique, $3^{e}$ éd. PUF. 佐野泰雄（訳）『レトリック』白水社 2000.

佐藤 裕 2005『差別論：偏見理論批判』明石書店.

Schön, D. A. 1993 "Generative Metaphor: A Perspective on Problem-Setting in Social Policy," A. Ortony (ed.) Metaphor and Thought, 2nd ed. Cambridge UP, pp. 137-163.

篠田博之 1995 「断筆宣言』をめぐる経緯」日本ペンクラブ（編）『「差別表現」を考える』光文社 pp. 223-228.

塩見鮮一郎 1993 『作家と差別語：表現の自由と用語規制のジレンマ』明石書店.

曽野綾子 1993 「筒井事件にみる言論の弾圧」再録：『大論争』pp. 96-98.

高橋哲郎 1993 「筒井康隆氏の覚書について」再録：『大論争』pp. 33-37.

筒井康隆 1983 「無人警察」『筒井康隆全集 第 1 巻』新潮社 pp. 232-237.

— 1993a「覚書」再録:『大論争』pp. 29-32.

1993b「断筆宣言」再録 :『大論争』pp. 38-39.

1993c『『文藝時評』最終回」再録：『大論争』pp. 44-49.

1994「これからの敵は、君たちマスコミだ」再録：『大論争』pp. 86-90.

八木晃介 1994『差別表現の社会学』法政出版.

安原 顯 1993 『し・つ・こ・くふざけんな!』図書新聞.

（明治学院大学／実践女子大学／大妻女子大学・非常勤講師・hysbr@ar.wakwak.com） 